\title{
Between Tradition and Modernity: Modern Confucianism as a Form of East Asian Social Knowledge
}

Jana S. RO ̌́KER*

\begin{abstract}
In the last decades of the 20th century, the revival of traditional Confucianism assumed increasing importance and relevance. The revitalization of its complex philosophical heritage thus became part of the most important theoretical currents in contemporary East Asian societies. Due to its potentially stabilizing social function and compatibility with capitalism, Confucianism is often seen as the Asian equivalent of Max Weber's "protestant ethic". In modern sinology, this view is known as the "post-Confucian hypothesis". The appearance of the "vacuum of values" in modern China and its problematization and connection to the transformation of the structure, role, and function of social knowledge provide a good example of the consequences of explosive social transformation. This also raises the question of whether the Confucian modernization model is indeed capable of generating a non-individualistic version of modernity. Proceeding from this hypothesis, the present paper aims to show that the purported relation between modernity and individualism, which international modernization theories have always viewed as "inevitable" or "intrinsic", is, in fact, little more than an outcome of Western historical paradigms.
\end{abstract}

Keywords: Confucianism, Modern Confucianism, cultural heritage, East Asian modernization, social knowledge

\section{Med tradicijo in modernostjo: moderno konfucijanstvo kot oblika vzhod- noazijskega družbenega vedenja}

\section{Izvleček}

V zadnjih desetletjih dvajsetega stoletja postaja preporod konfucijanstva v vzhodnoazijskih regijah vse pomembnejši. Ponovna oživitev njegove raznovrstne idejne in kulturne dediščine postaja $\mathrm{v}$ teh regijah vse vplivnejša. Idejno ozadje konfucijanstva pa sodi $\mathrm{k}$ osrednjim temam teoretske struje modernega konfucijanstva, ki se uvršča k najpomembnejšim diskurzom sodobne Vzhodne Azije. Njegovo zmožnost, da uravnoveša družbo in da je združljiv s kapitalističnim sistemom, pogosto primerjajo s funkcijami, ki jih je

* Jana S. ROŠKER, Professor, Department of Asian Studies,

Faculty of Arts, University of Ljubljana, Slovenia.

jana.rosker[at]ff.uni-lj.si

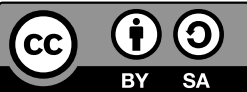


po Webru prevzela protestantska etika. V sodobni sinologiji se pogled na konfucijanstvo imenuje "post-konfucijanska hipoteza«. Problematizacija t.i. "vakuuma vrednot« v sodobni Vzhodni Aziji in njegova povezava $\mathrm{z}$ družbenim znanjem ter s transformacijo njegove strukture, njegovih vlog ter funkcij nam lahko služi kot dober primer posledic eksplozivnih družbenih sprememb. Vse to nas med drugim napeljuje na vprašanje o tem, ali je model modernizacije konfucijanstva sploh sposoben generirati ne-individualistično inačico modernosti. Izhajajoč iz te hipoteze bo obravnavani članek prikazal dejstvo, da je povezava med individualizmom in modernostjo, ki v večini klasičnih zahodnih teorij modernizacije velja za intristično oziroma nujno, v resnici zgolj rezultat zahodnih zgodovinskih paradigem.

Ključne besede: konfucijanstvo, moderno konfucijanstvo, kulturna dediščina, vzhodnoazijska modernizacija, družbeno znanje

\section{Introduction-Social Knowledge and the Confucian Revival in East Asia}

Proceeding from the notion of Confucianism as a form of social knowledge in East Asia, and speaking about its impact upon the specific features of East Asian modernization, we first have to clarify the meaning of these crucial terms within the referential framework of the present paper. In this paper, the term East Asia does not refer to a geographic or geo-political area, but rather to a cultural zone, one that is defined through various common cultural heritages, especially through the common Confucian ideational tradition. In this sense, Vietnam, for instance, is also part of East Asia, although in a strictly geographic sense it belongs to Southeast Asia.

When speaking about a "common Confucian tradition" we must ask ourselves how this term, which refers to a complex ideational system, relates to a common East Asian culture and its epistemology. Confucianism as a form of knowledge is a particularly important part of the ideas and ideologies underlying East Asian societies, and constitutes the main body of traditional learning ( $\mathrm{Li}$ and Yan 2006, 561). Various parts of this multi-faceted ideational system this form important elements of contemporary East Asian social knowledge. This is a form of knowledge that constitutes an epistemological common thread in societies, cultures, and communities. In contrast to personal knowledge, social knowledge is formed by a common ideational background, which provides a set of evaluative criteria that incoming information is assessed by. In other words: while personal knowledge and justification are based on the coherent integration of individual information, social knowledge and justification are based on the coherent aggregation of social information (Lehrer 1987, 87), as shared by individuals belonging to a certain 
social group. Here, we must also point out that this kind of social information is not limited to learning or perceiving what is conveyed or represented in the realm of factuality, but also includes ideas and values.

Confucianism as a form of knowledge has had a profound and widespread impact on traditional Asian societies ${ }^{1}$. However, social transformations in modern times have dislodged traditional and pre-modern forms of Confucianism from the centre of these societies ( $\mathrm{Li}$ and Yan 2006, 561). On the other hand, the revitalization of traditional Confucian thought is one of the most important intellectual currents in contemporary Eastern Asia. In China, which is the historical "cradle" of Confucian cultures and philosophies, this revitalization began on the threshold of the 20th century, and manifested itself in the intellectual current of the so-called New or Modern Confucianism (Xin ruxue ${ }^{2}$ ).

In international sinology, this line of thought is translated with various names, ranging from Neo-Confucianism or Contemporary or Modern Neo-Confucianism, to New Confucianism and Modern or Contemporary Confucianism. The first set, which includes the term Neo-Confucianism, is impractical because it is often confused with Neo-Confucianism (sic), a term that in Western sinology denotes the reformed Confucian philosophies of the Song and Ming periods (li xue or xingli xue). I therefore generally prefer the term Modern Confucianism, given that we are dealing with philosophical discourses that belong to Chinese modernity.

Because the Confucian renaissance as a new, modern intellectual movement started in China, its main representatives are also mainly found among modern and contemporary Chinese philosophers, although the Confucian revival is increasingly shaping the current academic scenes in other East Asian societies. In the present paper, however, we will concentrate upon the work of the central representatives of these currents who lived and worked (or still live and work) in the Chinese linguistic area. In order to clarify the abovementioned research question on the relation between Confucianism as a form of social knowledge on the one hand, and its impact upon the specific features of East Asian modernization on the other, we shall thus examine and introduce some of the most important epistemological elements contained in the writings of the most prominent representatives of this revival. These analyses will be based on the works of many philosophers belonging to all three

1 For scholars such as Joseph Levenson, Myron Cohen, and Margery Wolf, Confucianism is an outdated patriarchal ideology whose gradual disappearance is highly desirable, as this would open up areas for the consolidation of a new and much-needed cultural transformation. Instead, for other scholars, Confucianism is a sine qua non for any "Chineseness", and must thus be maintained and further developed in the contemporary world (Ames 2001, 71). 
generations of Modern Confucianism, ${ }^{3}$ including Xiong Shili, Zhang Junmai, and Liang Shuming from the first generation, Mou Zongsan, Xu Fuguan, Tang Junyi, and Fang Dongmei from the second, and Tu Weiming and Chen Lai from the third.

\section{Modern Confucianism and the Special Features of East Asian Modernization}

Modern Confucianism is defined by a search for syntheses between Euro-American and traditional East Asian thought. It aims to develop a system of values, ideas and concepts that could prove itself capable of resolving the social, political, and axiological problems of globalized modern societies. In order to establish a model in which modernization is not simply equated or confused with Westernization, scholars who belong to this stream of thought often attempt to revive "classical Confucian" values by adapting and reconciling them with the demands of the present time (see Tu 2000 and 2014).

In this context, it is important to consider the fact that since the latter half of the previous century East Asian societies have been constantly changing the map of world progress: as a result, the balance of economic and political power is shifting from the West to the East. This process has its roots in a number of transformations in ideational and material paradigms by which the development of East Asian regions can be defined, and which also strongly influence international relations at the global level. If we want to understand these transformations in the context of their individual cultural backgrounds, we must adopt a broader perspective, for their internal structures are by no means limited to (visible and measurable) economic, political, and ecological issues. On a deeper ideational level, these transformations are also tightly linked to the political and social roles of culturally conditioned values and ideologies. These — often only latently present—ideational factors represent the crucial axiological and epistemological foundations, as well as an inherent binding, of all the specific institutions that are typical for these societies. Confucianism undoubtedly is one of these key ideational foundations. It is based on the incorporation of ideas linked to the concept of a "relational self". The concrete collective social consciousness that underlies this mode of (self)-reflection manifests itself in the condition of the relational individual, who is necessarily and existentially an organic part of a social group. Such consciousness is reflected in the manner in which any given individuals come to view themselves as a part of a group, and in which patterns of commonality among individuals

3 The categorization into "generations" follows a long tradition in Confucian scholarship, which is ultimately rooted in classical Confucianism. 
bring explicit unity to inter-personal relations. This specific view of the relation between the individual and society has been of crucial importance for shaping the Modern Confucian version of "Chinese" or "East Asian Modernity", for in this renewed system the concept of individualism can be replaced by individualisation (Abbeg 1970, 210), i.e. in the full realization of each individual's potential within the relational network of their interactions with the "Others".

The prevailing classical Western modernization theories have created a tradition that interprets the relation between past and present (i.e. "tradition" and "modernity") in a Eurocentric manner, one that remains globally predominant even today. Although they differ from each other, they still have a common basis, established upon the supposition that "traditional" and "modern" cultures or societies always represent two systems of interrelated variables. In their various re-formulations of the dichotomy between tradition and modernity, this transition has been understood as a process in which the first one falls into decline and the latter is then established (Bendix 1967,307-8). As such, according to these theories social systems are grounded on a "before and after" model (ibid. 309). In this model "traditional" and "modern" social structures are distinguished by two sets of dichotomous attributes, and individual societies are classified as more or less "modern" according to the degree to which they exhibit one set of attributes rather than another (Rošker 2015, 13). In this context, tradition and modernity are widely used as polar opposites in a linear theory of social change. In such a view, the concept of change in economically growing societies, such as those seen in contemporary East Asia, can be understood as one which is conditioned by a linear development from a traditional, "conservative" past towards a "highly modernized" future. A significant presumption in this bipolar model of change is that the existing institutions and values that form the "content" of tradition are barriers to progress and social change, and are thus seen as obstacles to modernization (ibid.).

Following such ideas, most dominant Western theories of modernization have naturally assumed that East Asia could only develop a dynamic, modern society if it abandoned its most important traditional heritage, namely Confucianism. Indeed, Karl Marx and several other classical Western modernization theorists firmly believed that this ideational system was hindering any kind of real modernization in this part of the world. For example, Max Weber wrote extensively on Asia, especially India and China, concluding that Asian philosophical, religious, or cultural traditions could by no means serve as an ideational basis for social, political and economic modernization (Makeham 2003, 33).

On the other hand, Joseph R. Gusfield $(1967,351)$ pointed out that relations between "tradition" and "modernity" do not necessarily imply displacement, exclusiveness or 
conflicts. Hence, the "modern" must not necessarily or categorically impair the "traditional". He noted that traditional forms do not always hinder change and progress, but can also provide support for them.

Modern Confucian scholars also follow similar presumptions. Hence Weber's widely known thesis, according to which Protestant ethics were instrumental in the rise and spread of modernization, stands in contrast to a presumption that has appeared in Eastern Asia during recent decades, and which is known as the "post-Confucian hypothesis". This hypothesis argues that societies based on Confucian ethics might prove themselves not only as equal, but even superior, to the West in terms of modernization, industrialization, and affluence.

The abovementioned revitalization of Confucian thought, which first appeared at the threshold of the twentieth century and which developed in the theoretical stream of so-called Modern Confucianism, is certainly among the most important factors within such new modernization ideologies (Li 1996, 544). Contemporary Confucian scholars thus generally believe that the successful development of East Asian societies has been, and remains, mostly due to the particular modernization model that has been adopted, one known as "Confucian capitalism" (e.g. Kahn 1979; Vogel 1979).

This model is characterised by strong state leadership with a well-developed administrative structure, a hierarchical social structure with a well-developed network of social relations, and an emphasis on education. It also stresses virtues such as diligence, reliability and persistence together with cooperation, loyalty and a strong sense of affiliation with one's community or organization (Rošker 2015,3).

In order to acquire a more coherent understanding of the East Asian Confucian revival, its socio-epistemological functions in the modernization process, and its theories, it is also important to understand that it cannot be seen as a monolithic ideational formation. This revival includes a wide scope of theoretical discourses, which are rooted in a tradition that is already in itself very complex and heterogeneous.

\section{Epistemology and Axiology of Social Transformations}

Over the last few decades the developmental process of the Confucian revival has been tightly linked to the dynamic and complex social transformations seen in East Asian societies, in which it functions as one of the most important elements of common cultural heritage and social knowledge. In this context, social knowledge can also be defined as one's ability to understand and predict others' general 
patterns of behaviour. Therefore, social transformations are necessarily linked to simultaneous transformations of social knowledge. The revival of traditional Confucian values thus represents one of these ideational transformations.

As already noted, the Confucian revival is rooted in the presumption that East Asian modernization cannot be completely identified with Westernization, and that the process of modernization necessarily includes both universal and culturally conditioned elements. Here, we cannot forget that the term modernity, which generally denotes a period of social transformation, was developed within $\mathrm{Eu}-$ ro-American discourses, and thus defining the "general" theoretical evolution of this concept means (once again) addressing the development of Western theory. Hence, we should also stress that in this context that we are not referring to any notion of so-called "classic modernity", i.e. to the Western "New Era". We rather apply this term in the sense of a process of general social transformation or social revival, one linked to certain specific conditions that dictate modernization (e.g. the enlightenment movements, the dominant role and function of intellectuals, the spread of industrialization, and so on). Depending on the concrete specific tradition or specific cultural environment in which they took place, such processes followed different pathways. However, they always involved the transformation of many of the conditions defining transitional societies.

Since the latter half of the 20th century, Southeast Asia has been one of the most dynamic economies in the developing world. This process of economic change has always been accompanied by several other attributes of modernization, such as the spread of education, modern transportation systems, and mass media (Hirschman and Edwards 2007, 4376). The reasons underlying the economic success of some countries and the stagnation of others are still subject to dispute. The East Asian model of state-sponsored export industrialization is widely discussed in academic circles and among policymakers, but the parallels between East and Southeast Asian strategies of economic development remain rather unclear. An important element in this context is the presence of market-driven capitalism. However, the function of the regional governments in managing their economies has also been integral to economic development in the area. Hirschman and Edwards $(2007,4377)$ also points to the degree to which economic development in the region has been carried out by fairly authoritarian states. "The relationship between democracy and economic growth and development, argued to go hand in hand by modernization theorists, seemed to be challenged by the experience of Southeast Asian tigers towards the end of the twentieth century" (ibid.). However, a lot of research remains to be done to investigate the reasons for and implications of economic development and modernization in this area. 
In dealing with the relation between economic growth and democracy, we often come across the phrase "Asian values". This has often been used to express a key concept put forward by a number of authoritarian ideologies, which claims that, in order to contain the presumed threat and risks of "Western" individualism within in their own societies, there is a need to promote the "virtues" of Asian communitarianism and rigorous government.

"Asian values" as a doctrine of developmentalism can be understood as the claim that, until prosperity is achieved, democracy remains an "unaffordable luxury". This "Protestant ethic" form of "Asian values" attributes high growth rates to certain cultural traits. These characteristics include hard work, frugality, discipline, and teamwork. Western democracy hinders rapid development, claim authoritarian rulers in the East Asia, and thus must be delayed until substantial development has been achieved (Thompson 2001, 155-6).

This ideology thus warns against careless assumptions of "Western" democracy, arguing that it could lead Asian countries down the slippery slope of degeneration. In this way, "Asian values" have become the dichotomous opposite of everything that is seen as wrong with the West. The concept is very problematic, however, as it relies on the (wrongly understood) notion of "cultural relativism", or the idea that human rights are contingent upon Asian cultural heritage (Moody 1996, 166). In such contexts, Western countries are seen as having no right to impose their views, concepts and practices on other cultures.

Even though this notion of "Asian values" has often been closely identified with the Confucian tradition (see for example, Fetzer and Soper 2007; Yu 2000; de Bary 1998; Lee 2003), this expression, in fact, has almost nothing to do with the Modern Confucian scholars or their philosophies. Hence, it is very important to be aware of the significant differences between modern and contemporary adaptations of Confucian theory and the related discourse on Asian values, which is often mistakenly comprehended as forming part of the Modern Confucian stream of thought.

In general, this stream of thought has nothing much against Western influences, as it is even based upon searching for syntheses between Euro-American and traditional Chinese (especially Confucian) discourses. The founders of Modern Confucianism as a system aimed at a more systematic re-interpretation of traditional Chinese philosophy and culture, based on a deeper and more comprehensive understanding of Western philosophy, especially the thought of Plato, Kant and Hegel, as well as other representatives of German Idealism. Given that 
Modern Confucians viewed modernization primarily as a rationalization of the world, they explored their own tradition for authentic concepts comparable to the two Western paradigms essential for modernization, i.e. the concepts of subjectivity, and of reason and rationality.

However, this stream of thought also aims to elaborate and modernize some Confucian values that could be used as a counterweight to the general dispersion of values, which is typical for industrial and post-industrial societies. Because one of the central axiological elements accompanying profit-driven capitalistic developments is widespread social alienation, traditional ideational systems have-inter alia-been investigated in order to find a solution to the so-called "vacuum of values" that appear as an omnipresent manifestation of this phenomenon. In this context, Modern Confucianism aims to elaborate on traditional epistemological approaches linked to the inherent connections between knowledge and values or knowledge and wisdom, focusing on the cultural and axiological conditionality of comprehension. In this sense, Confucian philosophers have followed the presumption that traditional epistemological and ethical concepts could serve as a foundation for an "East Asian" modernization theory.

\section{Knowledge and Value}

In order to obtain a deeper understanding of the contributions of Modern Confucianism to the solving of the global crisis of values, the present paper will critically introduce the epistemological thought of some of its most important representatives. It aims to show the development of the traditional Chinese epistemological presumption that moral cultivation is a precondition for any comprehensive knowledge. An implication of this premise is that human perception and comprehension of reality, which is, in itself, permeated by ethical values ${ }^{4}$, is not only rational, for it is, among other factors, also defined by intentions, desires, and feelings. Modern Confucians assume that the very same demarcation line that divides reason and intuition also divides science and philosophy or the humanities.

In general, Modern Confucians do not oppose science, but are against scientism. Moreover, most of them argue that science, which aims at the recognition of objects in the external natural world by applying rational and analytical methodology, will never be able to solve questions linked to the meaning of life, nor have a significant impact on an individual's worldview. While science explores facts,

4 On this basis, the contemporary Chinese philosopher Chen Lai elaborated an ontology of the central Confucian virtue of humanness $(r e n)$ and introduced a vision of a humanness-based ethics, pertinent to modern times (Lai 2014). 
philosophy and the humanities investigate meanings and values. As such, Modern Confucians claim that the boundary between reason and intuition not only separates science and philosophy, but also the realm of phenomena from that of values (see for instance Xiong 1992, 357; Mou 1995, 549; Fang 1936, 160; Xu 1960, 2; Tang 2000, 293 etc.).

Here we shall take into account that in the holistic Confucian tradition epistemology is inseparable from ontology, since every object of cognition is also cognition itself. The concrete manner of an object's existence is therefore tightly linked to our understanding of it. This link is interactive, for it includes mutual co-dependency. We thus cannot oversimplify the Confucian view by claiming that it represents a solipsistic conceptualisation of the world. What is true for the perception of the external world also holds for its comprehension and interpretation, which cannot be separated from the whole, but individualized and thoroughly changeable, existence of the objects of cognition.

The main streams of thought in traditional Chinese epistemology were primarily based on the method of introspection and the intuitive perception of reality. In the Neo-Confucianism of the Song (960-1279) and Ming (1368-1644) Dynasties (upon which the majority of Modern Confucian discourses are grounded), there were two schools: the first was "realistic", and was known as the School of the Structure (Li xue 理學) or the School of Reason (Xingli xue 性理學). Greatly influenced by the teachings of the most important medieval Chinese philosopher, $\mathrm{Zhu} \mathrm{Xi}$, this epistemology emphasizes realistic modes for the perception of reality, and it introduced a new methodology suited to this form of recognition called "exploring objects" (ge wu 格物). The latter school, which instead advocated more idealistic and intuitive methods of recognizing reality, was named the School of the Heart-Mind (Xin xue 心學), and was led by the most famous philosopher of the Ming Dynasty, Wang Shouren ${ }^{5}$. Most Modern Confucian philosophers are more influenced by this latter school of thought than by the more realistic philosophy of Zhu Xi. Moreover, they derive their concept of reason from German philosophy, which generally occupies an important position in their theories.

While in China, Marxist theoreticians (such as Jin Yuelin) prescribed absolute priority to the rational method, most Modern Confucians (especially Xiong Shili and Mou Zongsan) applied the intuitive one. Some of them, however, like Liang Shuming (1924, 97-102) and Zhang Junmai (Chang 1954, 100), drew attention to the traditional binary understanding of reason and intuition. Here, the two methods of inquiry are not only linked to each other, but are also connected to the method of reasoning as such, because reasoning is always based on distinguishing.

$5 \quad$ Also known as Wang Yangming. 
In such a view, philosophers who apply the method of intuition at the same time must also apply methods of formal logic and dual differentiations; and those who apply the rational method simultaneously use the intuitive one, as well as dual distinctions ${ }^{6}$. For Modern Confucians, all these methods-those of dual distinctions and intuition, as well as of formal analysis and inferences-are necessary components for any coherent philosophical activity. However, the recognition obtained from intuitive perception is deeply rooted in cognition, human will, and feelings, and thus represents a synthesis on a high epistemological level. Zhang Junmai, for instance, pointed out that this synthesis cannot be established by study alone, in which intuition and reason appear in a mutually contradictory relation, but only on the basis of much broader platforms (Chang 1954, 100). In this context, Xiong Shili and his student Xu Fuguan upgraded Wang Shouren's method of recognition, which they called tiren 體認 (bodily recognition) and tizhi 體知 (knowledge obtained through the body), respectively. This method is not based on intuition in the usual sense, nor on rational reasoning about the logical relations between premises and inferences. Instead, tiren is a retrospective and active process in which "the subject discovers moral subjectivity in the pseudo-subjectivity of human desires and affirms and develops it" (Ni 2002, 287). Here, the word "ren" (recognition) means both realization and recognition. One reveals one's own moral nature through "overcoming the self" and by "reducing sensual desires" (ibid.).

Most Modern Confucian philosophers are also profoundly interested in questions regarding the nature of the relation between theory and praxis, i.e. between "knowledge and action" (zhi xing 知行), which also represented one of the central epistemological problems of traditional, especially Neo-Confucian, discourses ${ }^{7}$ (see for instance He Lin 1938).

In the traditional Confucian conceptual and referential frameworks, the transcendent and empirical spheres of human performance mostly correspond to the dual antipodes of “inner sage" and “external ruler" “"neisheng 內聖” and “waiwang 外 王”). As Lee Ming-Huei points out (2001, 15), most Modern Confucians see the "inner sage" as a foundation for the concept of the "external ruler". However, the latter cannot be understood only as a kind of extension of the former. Due to their striving to establish an East Asian theory of modernization, Modern Confucians

6 The comprehension of reality based on the method of dual differentiation and distinction, respectively, is rooted in the awareness of binary oppositions like hard-soft, black-white, pleasure-pain, etc. They form a contrast, through which objects can be easily categorized and hence integrated into the comprehensive perception of reality.

7 In the framework of the Neo-Confucian philosophy (i.e. the reformed Confucian discourses from the Song and Ming Dynasties), this view has been elaborated in greatest detail by Wang Shouren and some other representatives of the School of the Heart-Mind (Xin xue). 
aim to establish within the complementary relation between the two polar opposites something similar to the Western conception of the subject.

A subject so constituted could thus unite in itself the awareness of the "subject of moral practice" (daode shijiande zhuti) in the sphere of spiritual life, the awareness of the "political subject" (zhengzhi zhuti) in the field of society, and the awareness of the "cognitive subject" or the "subject of recognition" (renshi zhuti) in the realm of epistemology and the natural world. The inner sage thus had to be posited in the complementary relation with a "new external ruler" (xin waiwang) who was responsible for the development of science and democracy. (Rošker 2016, 156)

In this process of recognition, the unity of knowledge and action (zhixing heyi 知 行合一), as well as the subject and object of recognition, merge into unity. If the subject of recognition wants to gain objective knowledge, it must "immerse" (Ni 2002 , 292) itself in the object of recognition, i.e. in all that can be recognized in that object. Only in this way can a certain insight becomes genuine knowledge. On such a basis, the separation between knowledge and the subject of recognition can be completely eliminated, and the incorporation of what has been recognized becomes a precondition for its actual and complete recognition.

In the Neo-Confucian philosophies of the Song and Ming Dynasties, the intuitive recognition of reality was closely linked to the concept of innate knowledge (liangzhi 良知), which constitutes the core of the moral nature of any individual. This concept, which can be seen as a creative link connecting fact and value, has profoundly influenced the entirety of Modern Confucian epistemology. For Xiong Shili $(1992,548)$, one of the pioneers of Modern Confucian stream of thought, this innate knowledge, which manifests itself in the infinite heart-mind (wuxiande zhixin 無限的知心) and its phenomenal form denoted by the original heart-mind (ben xin 本心), is the basic human moral substance and provides a foundation of moral performance; it is transcendent and infinitely universal ${ }^{8}$. Many later Modern Confucians, such as Mou Zongsan $(1995,38)$ and Tang Junyi $(1985,53-54)$, have seen it as a kind of moral compass intrinsic to every individual. Similarly, Xu Fuguan appropriated the traditional concept of moral reason (daode lixing 道德理性), which serves as a fundamental principle for the guidance and regulation of human life within the moral heart-mind, and manifests itself

8 The human heart-mind ( $x$ in) as a necessary and constitutional part of the inner moral substance (or the inherent individual moral Self) is the key component in the recognition process. When recognizing other human beings, this sensual compatibility must also be based on empathy, a core notion defining the abovementioned central Confucian virtue of humanness (ren). 
as an awareness of the good and ethical within the moral Self or original heartmind (Xu 2005, 178). Most Modern Confucian epistemological discourses are also based on the presumption that this awareness is innate to all human beings.

All this led to a modern elaboration of the traditional Confucian moral spirit, which is both immanent and transcendent. The Modern Confucian elaborations of such a moral spirit are based on the internalization of traditional religious concepts, which were transformed and changed from abstract external ideas into symbols denoting different existential forms of the inner moral substance (ibid.).

As already noted, Modern Confucian epistemology is closely related to its ontology, for scholars belonging to this current usually see the world as a metaphysical reality that is immanent to all that exists in the universe, while also possessing moral qualities (Chan 2002, 306). In this respect, the central Confucian virtue of (co)humanness or mutuality (ren 仁) is already part of the cosmic entirety (see Chen 2014), while its recognition, or its simultaneous incorporation and internalization, manifests itself in the moral performance of individuals. Chen Lai, who is one of the most important current Chinese philosophers, also points out that the ideational foundations of this virtue form a basis for a unification between the Self and Other, since they are rooted in an awareness of the importance of community, and thus in an awareness of one's own social responsibility (Chen 2014a, 41).

\section{Knowledge and Wisdom}

This kind of ethically conditioned knowledge is also tightly connected to the notion of wisdom, or, in other words, to the differentiation between factual and axiological knowledge. In contrast to the former, the latter is not only grounded in perceiving, gathering, and applying factual information, but also includes its concrete evaluation, allowing us to apply it in reasonable and ethically irreproachable ways. This kind of knowledge is grounded in an ethically aware understanding and evaluating of different positions in various social contexts. It is rooted in the difference between facts and values, i.e. in a classical epistemological distinction, which appeared in almost all traditional philosophies, and which has gained a lot of attention in modern times in the form of the increasingly problematic relation between science and humanities.

Hence, throughout the twentieth century, various attempts at clarifying the relation between knowledge and wisdom emerged to the forefront of Modern Confucian philosophies. This task implied the need for a transformation of these traditional discourses, which could not be comprehended, applied, reproduced, 
or developed beyond the specific frameworks of the Chinese tradition. Hence, this aspect has been connected to the need for the analytical reconstruction of traditional concepts in the context of social modernization. Most of the Modern Confucians were well aware of the importance of this task, for it preconditioned any possibility of adapting these frameworks to the modern era and, hence, of turning them into a possible foundation of new, contemporary social knowledge. In these endeavours they aimed to fill the emerging "vacuum of values", which manifested itself in social dispersion and a complete lack of generally binding axiological norms or criteria.

Many Modern Confucians elaborated on the concept of wisdom, as can already be found in Xiong Shili's theories on the difference between qualitative ( $x$ ingzhi 性智) and quantitative (liangzhi 量智) understanding (Rošker 2009, 376). In his Three Kinds of Philosophical Wisdom (Zhexue san hui, 2007), Fang Dongmei also unites the notions “li 理” (reason) and “qing 情” (feeling, sensation) into an epistemological concept of “sensuous reason (qingli 情理)”. In its unification of rationality and feelings, this notion provides a fundamental and original core, or basis of recognition. Fang thus denoted it as a "seed of wisdom" (zhihui chongzi 智慧种子). Tang Junyi’s epistemology also implies both a theory of knowledge and a theory of wisdom. In Tang's philosophy, intuition and reason are thoroughly interconnected. Based on this interconnection and the mutual influence amongst the different mechanisms and segments of the heart-mind, and with the help of analytical philosophy, Tang formulated an innovative and very interesting hypothesis regarding the creativity of wisdom (zbibuide chuangzaoxing 智慧的創造性). For him, knowledge (zhishi 知識) includes ideas or concepts, logical cognitive laws, inferences, and empirical intuition. Wisdom, however, is understood as a kind of "miraculous creativity" (shenmiaode chuangzaoxing 神秒 的創造性), i.e. a type of intuitive reasoning that is neither completely empirical, nor exclusively rational. It is a kind of thought that can apply previously obtained knowledge, but only based on prior independent decisions for such application. As such, knowledge is both integrated and surpassed. In both theories, morality plays a central role, because it represents the foundation of the Self and thus of the heart-mind. In this regard, Tang argues that his concept of rational intuition is able to directly "penetrate" the patterns that were established on the grounds of synthesizing premises, and so can rather easily obtain valid conclusions. This, of course, implies that rational intuition is above logical reason. At the same time, however, Tang believes that pure rational intuition can only lead to knowledge and not wisdom, because it is only capable of non-inferential reasoning. He has also never fully elaborated on or analysed in detail his notion of "miraculous creative wisdom." All that can be said of this idea is merely that it 
is founded on the moral heart-mind, which is understood as a vital part of the human Self, and that it functions instantly and unconsciously.

In contrast, Mou Zongsan criticized the traditional concepts of intuition and wisdom, claiming that they have had a devastating impact on Chinese history:

Historically, Confucian theoretical works had always treated intuition as a manifestation of the personality of a sage or a saint, i.e. in terms of the magical effects of wisdom... These effects were always posited within humanity (or mutuality, ren), and therefore could not be separated from it, even temporarily, in order to gain "pure recognition". This is why logic and mathematics were never developed in $\mathrm{China}^{9}$ (Mou Zongsan in Han and Zhao 1994, 176).

However, on the basis of elaborating and synthesizing Kant's epistemology, Mou also developed a concept of specifically Chinese intellectual intuition (zhide zhi$j u e$ 智的直覺) that enabled people to perceive and comprehend not only objects from the phenomenal world, but also the sphere of noumena ${ }^{10}$. When manifest in humans, this kind of "divine recognition" (Mou 1971, 51) is certainly a kind of wisdom.

The traditional Confucian notion of wisdom was also developed and modernized by several philosophers, who until recently have not been seen as Modern (or contemporary) Confucians, but rather as purely Marxist theoreticians. This holds particularly true for Jin Yuelin's student Feng Qi, and his innovative work in the development of Chinese epistemology.

While Jin Yuelin's theories of knowledge were based upon the traditional Western understanding of epistemology as a discipline limited to a pure theory of knowledge, Feng attempted to extend this approach and, based on traditional Chinese discourses, sought to create an epistemology in a broader sense, which he called “expanded epistemology” (guangyi renshi lun 廣義認識論).

He believed that epistemology should not be limited to the theory of knowledge, but should also include the problem of exploring wisdom. In this context, he strove to consider all the basic approaches to the main philosophical issues

9 在以前的儒家學術發展中, 始終是停在聖賢人格中的直覺形態上, 及智慧輝妙用的型態...它 總是上屬而渾化於仁中, 而未暫時脫離呼仁而成為 »純粹的知性《. 因此, 邏輯數學都出不來.

10 Mou Zongsan tried to define the position of reason within traditional Chinese thought by comparing Western and Chinese cultures, arguing that they were based on different representational forms of human reason. He called the Chinese form "functional or intensive" (lixingzhi yunyong biaoxian 理性運用表現) and the Western “constructive or extensive” (lixingzhi jiagou biaoxian 理性架構表 現) (Mou 1995, 544-53). 
of both ancient and modern times. For him, these basic approaches were clearly expressed in both Western metaphysical inquiries and in the ancient Chinese methods of cultivating the ideal personality. Similar endeavours were also clearly visible in his general philosophical and/or methodological research, through which he tried to establish a new approach to solving the contradiction between the natural sciences and humanities. His attempt to transcend the boundaries between ignorance and knowledge, and his theory of distinguishing between knowledge and wisdom, not only referred to epistemological problems, but also implied ontological and metaphysical issues. By consistently integrating ontological and ethical suppositions into the framework of his "expanded epistemology," Feng provided a unique and original solution to the dichotomous relations of substance and phenomena. His epistemological system, which included systematic, rational distinctions, as well as a holistic reunification of comprehension, was a felicitous attempt at establishing a theoretical framework that could provide the basis for fresher, more complex methodologies in contemporary theoretical discourses (Feng 1983, 54).

For Chen Lai, wisdom belongs to the four central Confucian virtues, which are categorized into ethics (Chen 2014, 251). Confucianism, since the time of Confucius, emphasizes "practical wisdom" as the realization of philosophy:

This approach accentuates the practical aspects of wisdom rather than the analytical rationale of the intellect.

Emphasison practical wisdom persistently reinforces a moral foundation that is not differentiated from personal virtue. At the same time, practical wisdom in Confucianism stresses self-cultivation, or the complete transformation of the self, derived from the internal state of the heart/ mind (xin). Finally, Confucianism insists that practical wisdom must be transformed into practical action. (Chen 2015,69)

In his commentaries on Feng Youlan's philosophy, Chen Lai also exposes the difference between moral and intellectual (or, in Feng's own words, "non-moral") knowledge, pointing out that they belong to two different categories of rationality. These two types of rationality must be sharply distinguished, for the objects of moral rationality are moral principles, whereas those of intellectual rationality are existing laws (Chen and Xin 2007, 368). He also lays stress upon the fact that one of the main critiques of Confucianism by classical Western theories of modernization was centred on said theories' suppositions that Confucian ethics were incompatible with the rationalization inherent in the process of modernization. In this regard, the very Confucian concept of wisdom was seen as one 
of the main culprits for this "incompatibleness," because Confucianism allegedly "stressed the wisdom of feelings rather than knowledge born of experience and assessment" (Chen 2009, 234). This was one of the central claims in the theories of Talcott Parsons, Weber's successor, who in the 1960s established the hypothesis that Confucianism was an obstacle to modernization. However, only a decade later the prevailing opinion on the relation between Confucianism and modernization had radically changed not only in the Asian academic world, but also in the Euro-American one.

\section{Conclusion}

As we have seen above, the Modern Confucian emphasis on the traditional Confucian link between comprehension and the ethical evaluation of being is an important part of the related epistemology. This epistemology, which cannot be separated from ontology, is of utmost importance for the gradual restoration of the "credibility" of ancient Chinese thought in the context of modern social knowledge. In the framework of such onto-epistemological discourses, the imparting of meaning does not refer solely to the subject, but also to his or her intimate connection with fellow human beings who are thus seen as being something more than just the "Others". In this sense, such discourses could be well on their way to establishing a new, specifically East Asian model of modernity. Such a model is by no means grounded in individualism, (which is, in the framework of classical Western modernization theories, an absolutely necessary precondition for any kind of modernization), but rather in the abovementioned notion of individualization.

A subject in the sense of a moral Self, who is--in addition to analytical and rational skills also endowed with intuition and wisdom, represents one of the possible Modern Confucian responses to the global questions of the present time. These questions are linked to the dilemmas of the modern subject who is trapped within the complex technologies of the profit-seeking natural world, and has thus forgotten the ethical dimensions which define his or her humanity. A new East Asian social epistemology, which could be based upon the Confucian notions of values and wisdom, might represent an instrumental factor in reviving traditional values and sensibly adapting them to the requirements of the new social knowledge, making them suitable for the lives of people in both modern and post-modern eras. The digital period in which we live is defined by an overflow of factual, auditory, and visual information, along with the accompanying overburdening of people's sensory organs. In such times, wisdom, 
which is a characteristic feature of Confucian sages, can be more than useful, especially considering the fact that the original meaning ${ }^{11}$ of the Chinese term sage (sheng ren) is "one who listens carefully".

\section{References}

Abbeg, Lily. 1970. Ostasien denkt anders - eine Analyse der West-Östlichen Gegensätze. München: Verlag Kurt Desch.

Ames, Roger T. 2001. "New Confucianism: A Native Response to Western Philosophy." In Chinese Political Culture 1989-2000, edited by Hua Shiping, 7099. London and New York: M.E. Sharp, East Gate Books.

de Bary, William Theodore. 1998. Asian Values and Human Rights: A Confucian Communitarian Perspective. Cambridge, Ma: Harvard University Press.

Bendix, Reinhard. 1967. "Tradition and Modernity Reconsidered." Comparative Studies in Society and History 9 (3): 292-346.

Chan, Sin yee. 2002. "Tang Junyi: Moral Idealism and Chinese Culture." In Contemporary Chinese Philosophy, edited by Cheng Chung-Ying in Nicholas Bunnin, 235-346. Oxford: Blackwell Publishers.

Chang, Carsun. 1954. "Reason and Intuition in Chinese Philosophy." Philosophy East and West 4 (2): 99-112.

Chen, Lai. 2009. Tradition and Modernity - A Humanist Vierw. Translated by Edmund Ryden. Leiden, Boston: Brill.

— 陳來. 2014. Renxue bentilun 仁學本體論 (The Ontology of Ren). Beijing: Sanlian shudian.

—. 2014a. “Renxue bentilun 仁學本體論 (The Ontology of Ren)." Wen shi zhe 4: 41-63.

—. 2015. "Practical Wisdom in Confucian Philosophy." Journal of Philosophical Research; Supplement, 69-80.

Chen, Lai, and Xin Yan. 2007. “'After-sage' Life Pursuits: The Ethical Meaning of Feng Youlan's Xin Shixun.” Frontiers of Philosophy in China 2 (3), June: 363-78.

Fang, Dongmei 方東美. 1936. Kexue, zhexue yu rensheng 科學, 哲學與人生 (Science, Philosophy and Human Life). Beijing: Shangwu yinshu guan.

—. 2007. Zhexue sanhui 哲學三慧 (Three Types of Philosophical Wisdom). Taibei: Sanmin shuju.

11 In the oldest Chinese etymological dictionary from the Han Dynasty Shuowen jiez $i$ 說文解字, the character sheng 聖 (sage, the wise person) is explained as 從耳呈聲, which means that the sound appears through the ears. 
Feng, Qi 馮契. 1983. Zhongguo gudai zhexuede luoji fazhan 中國古代哲學的邏 輯發展 (The Logical Development of Ancient Chinese Philosophy), 3 Volumes. Shanghai: Shanghai renmin chuban she.

Fetzer, Joel S., and Christoper J. Soper. 2007. "The Effect of Confucian Values on Support for Democracy and Human Rights in Taiwan." Taiwan Journal of Democracy 3 (1): 143-54.

Gussfield, Joseph R. 1967. "Tradition and Modernity: Misplaced Polarities in the Study of Social Change." American Journal of Sociology 72 (4): 351-62.

Han, Qiang 韓強, and Zhao Guanghui 趙光輝. 1994. Wenhua yishi yu daode lixing - Gang Tai xin rujia Tang Junyi yu Mou Zongsande wenhua zhexue 文化意識 與道德理性 - 港台新儒家唐君毅與牟宗三的文化哲學 (Cultural Awareness and the Moral Self - the Cultural Philosophy of TangJunyi and Mou Zongsan from Hong Kong and Taiwan). Shenyang: Liaoning renmin chuban she.

$\mathrm{He}$, Lin 賀麟. 1938. Zhixin heyi - xin lun 知行合一新論 (ANerw Discussion on the Combination of Knowledge and Practice). Beijing: Beijing daxue chuban she.

Hirschman, Charles, and Jennifer Edwards. 2007. "Social Change in Southeast Asia." In The Blackwell Encyclopedia of Sociology, Vol. 9, edited by George Ritzer, 4374-80. Oxford: Blackwell Publishing.

Kahn, Hermann. 1979. World Economic Development: 1979 and Beyond. Boulder: Westview Press.

Lee, Hong-jung. 2003. "Development, Crisis and Asian Values.” East Asian Review 15 (2): 27-42.

Lee, Ming-Huei 李明輝. 2001. Dangdai ruxuede ziwo zhuanhua 當代儒學的自 我轉化 (The Transformation of Contemporary Confucianism). Beijing: Zhongguo shehui kexue chuban she.

Lehrer, Keith. 1987. "Personal and Social Knowledge." Synthese 73 (1): 87-107.

Li, Jinquan 李錦全, ed. 1996. Xiandai xin rujia xua’an 現代新儒家學案 (Modern Neo-Confucianism). Vol. 3. Beijing: Zhongguo shehui kexue chuban she, 543-58.

Li, Xiangjun, and Yan Xi. 2006. "A Reconstruction of Contemporary Confucianism as a Form of Knowledge." Frontiers of Philosophy in China 1 (4): 561-71.

Liang, Shuming 梁漱溟. 1924. Liang Shumin sanshi qian wenlu 梁漱溟三十前文 錄 (Liang Shuming's Early Works). Shanghai: Dongfang Wenku.

Makeham, John, ed. 2003. New Confucianism. A Critical Examination. New York: Palgrave Maximilians.

Moody, Peter R. Jr. 1996. “Asian Values.” Journal of International Affairs 50 (1): 166-92.

Mou, Zongsan 牟宗三. 1971. Zhide zhijue yu Zhongguo zhexue 智的直覺與中國 哲學 (The Intellectual Intuition and Chinese Philosophy). Taipei: Taiwan shangwu yinshu guan. 
—. 1995. “Zhengdao yu zhidao, di san zhang 政道與治道, 第三章 (The Way of Politics and the Way of Order)." In Xiandai xin ruxue xue'an, Vol. 3, edited by Fang Keli 方克立 and Li Jinquan 李錦全, 544-53. Beijing: Zhongguo shehui kexue chuban she.

Ni, Peimin. 2002. "Practical Humanism of Xu Fuguan.” In Contemporary Chinese Philosophy, edited by Cheng Chung-Ying and Nicholas Bunnin, 281-304. Oxford: Blackwell Publishers.

Rošker, Jana S. 2008. Searching for the Way: Theories of Knowledge in pre-Modern and Modern China. Hong Kong: Chinese University Press.

—. 2009. "Modern Confucian Synthesis of Qualitative and Quantitative Knowledge: Xiong Shili.” Journal of Chinese Philosophy 36 (3): 376-90.

—. 2015. "The Confucian Revival and 'Different Models of Modernity'." In Contemporary East Asia and the Confucian Revival, edited by Jana S. Rošker and Nataša Visočnik, XIII-XXIV. Newcastle upon Tyne: Cambridge Scholars Publishing.

—.2016. The Rebirth of the Moral Self: the Second Generation of Modern Confucians and their Modernization Discourses. Hong Kong: Chinese University Press.

Tang, Junyi 唐君毅. 1985. Daode ziwozhi jianli 道德自我之建立 (The Establishment of the Moral Self). Taipei: Xuesheng shuju.

—. 2000. Renwen jingshenzhi chongjian 人文精神之重建 (Reestablishing the Spirit of Humanities). Taipei: Xuesheng shuju.

Thompson, Mark R. 2001. "Whatever Happened to 'Asian Values'?" Journal of Democracy 12 (4): 154-65.

Tu, Weiming. 2000. "Implications of the Rise of 'Confucian' East Asia." Daedalus 129 (1): 195-219.

—. 2014. "Confucianism." In Encyclopaedia Britannica. Accessed March 13, 2014. http://global.britannica.com/EBchecked/topic/132104/Confucianism /25455/The-historical-context\#ref1008344.

Vogel, Ezra F. 1979. Japan as Number One. Cambridge: Harvard University Press. Xiong, Shili 熊十力. 1992. Xiong Shili lunzhu ji zbi yi 熊十力論著集之一 (Collected Works of Xiong Shili, Part 1 /Xin weishi lun/). Beijing: Zhonghua shuju. Xu, Fuguan 徐復觀. 1960. “Bu si bu xiangde shidai 不思不想的時代 (A Time without Reasoning).” Huaqiao ribao April 12.

—. 2005. Zhongguo renxing lun shi 中國人性論史 (The History of Human Nature). Beijing: Huadong shifan daxue chuban she.

Yu, Anthony C. 2000. "Which Values? Whose Perspective?" The Journal of Religion 80 (2): 299-304. 